\title{
Prospek Penerapan Online Dispute Resolution dalam Upaya Penyelesaian Sengketa Bisnis di Indonesia
}

\author{
Muhammad Azwar \\ muhammadazwarr@gmail.com \\ Universitas Airlangga
}

\begin{abstract}
Online dipute resolution that have not been resolved in Indonesia so that developments in information, technology and business cannot be completed with positive legal requirements. The researcher in this matter discusses the prospect of applying online dispute resolution as a model for solving business disputes in Indonesia. The method of discussion used is discussion of invitations, conceptual consultations, and futuristic discussions. From the results of this study, it was obtained from an online discussion which is one form of modern renewal of disputed agreements consisting of those developed with technology and the internet through cyberspace by providing and supporting business people in balancing the pace of global trade, technology and information so fast.

Keywords: Online Dispute Resolution; Business Disputes; Business Law; Special Civil Procedure Law.
\end{abstract}

\begin{abstract}
Abstrak
Penyelesaian sengketa secara online belum diatur secara eksplisit di Indonesia sehingga perkembangan yang pesat dari informasi, teknologi, dan bisnis tidak dapat seimbang dengan aturan hukum positif. Peneliti dalam hal ini membahas prospek penerapan online dispute resolution sebagai model penyelesaian sengketa bisnis di Indonesia. Metode pendekatan yang digunakan adalah pendekatan perundang-undangan, pendekatan konseptual, dan pendekatan futuristik. Dari hasil penelitian ini didapatkan bahwa penyelesaian sengketa secara online merupakan salah satu wujud pembaharuan secara modern dari penyelesaian sengketa alternatif yang merupakan penyelesaian yang dikembangkan dengan teknologi dan internet melalui dunia maya dengan memudahkan dan menguntungkan para pelaku bisnis dalam upaya penyelesaian sengketa yang timbul sehingga hukum positif dapat mengimbangi laju perdagangan global, teknologi, dan informasi yang begitu cepat.

Kata Kunci: Penyelesaian Sengketa secara Online; Sengketa Bisnis; Hukum Bisnis; Hukum Acara Perdata Khusus.
\end{abstract}

\section{Pendahuluan}

Globalisasi ditandai oleh perkembangan dan kemajuan teknologi elektronik yang sangat pesat yang mempengaruhi hampir seluruh aspek kehidupan dan kegiatan masyarakat. Berkembangnya teknologi modern dan terbukanya jaringan informasi global yang serba transparan menghasilkan gejala masyarakat gelombang ketiga yang telah ditandai dengan munculnya internet. ${ }^{1}$ Teknologi internet mempunyai

${ }^{1}$ Benjamin Wreight, The Law of Electronic Commerce (3rd edn, Aspen Law and Businesses 2001).[13-15] sebagaimana yang dikutip Abdul Halim Barkatullah, Sengketa Transaksi E-Commerce Internasional (Nusa Media 2010).[1]. 
pengaruh yang sangat besar terhadap perekonomian dunia. Internet membawa perekonomian dunia memasuki babak baru yang lebih populer dengan istilah ekonomi digital. Keberadaannya ditandai dengan semakin maraknya kegiatan perekonomian yang memanfaatkan internet sebagai media komunikasi, kolaborasi, dan kooprasi. ${ }^{2}$

Dalam dunia perdagangan saat ini telah berkembang 2 (dua) model utama perdagangan yaitu model perdagangan bisnis konvensional dan model perdagangan modern atau disebut bisnis modern. Teknologi internet digunakan sebagai sistem perdagangan yang inovatif memungkinkan terjadinya transfer informasi secara cepat ke seluruh penjuru dunia melalui dunia maya. Informasi ditempatkan sebagai komoditi ekonomi yang sangat penting dan menguntungkan. Salah satu aspek aktifitas ekonomi yang menggunakan teknologi informasi adalah dalam hal bertransaksi dengan menggunakan media internet yang dikenal dengan e-commerce. ${ }^{3}$

E-commerce merupakan transaksi perdagangan antara 2 (dua) pihak yakni pihak penjual dan pihak pembeli dengan menggunakan media internet. Pertumbuhan penggunaan internet telah menjadi salah satu media yang efektif bagi perusahaan maupun perseorangan untuk memperkenalkan dan menjual barang atau jasa kepada konsumen keseluruh dunia. E-commerce merupakan bisnis modern yang meniadakan suatu transaksi yang mana dalam bisnis yang konvensional mewajibkan kehadiran para pihak dan kertas-kertas sebagai dokumen yang harus dilengkapi. Model bisnis ini lebih bersifat non face dan non sign. ${ }^{4}$

\footnotetext{
${ }^{2}$ Topio Puurunen, 'The Judicial Juridiction of States Over International Busines to Consumer Electronic Commerce from The Perspective of Legal Certainty' [2002] Journal of International Law and Policy.[207].

${ }^{3}$ Syamsiah Amali, 'Pemanfaatan Internet Pada Pelajar Di Kota Gorontalo' Jurnal Penelitian dan Komunikasi Opini Publik <https://kolomberbagi.files.wordpress.com/2011/10/pemanfaatan-internet-pada-pelajar-di-kota-gorontalo.pdf $>$.[17] sebagaimana dikutip Rochani Urip Salami dan Rahadi Wasi Bintoro, 'Alternatif Penyelesaian Sengketa Dalam Sengketa Transaksi Elektronik (E-Commerce)' (2013) 13 Dinamika Hukum.

${ }^{4}$ Adel Chandra, 'Penyelesaian Sengketa Transaksi Melalui Online Dispute Resolution (ODR) Kaitan Dengan UU Informasi Dan Transaksi Elektronik No. 11 Tahun 2008' (Esa Unggul, 2014) $<$ https://digilib.esaunggul.ac.id/penyelesaian-sengketa-transaksi-elektronik-melalui-online-dispute-resolution-odr-kaitan-dengan-uu-informasi-dan-transaksi-elektronik-no11-tahun-2008-3653. html $>$ accessed 15 January 2019.
} 
Kemajuan teknologi internet yang sangat cepat tidak dapat diimbangi dengan perkembangan hukum yang lebih lambat, hal tersebut dapat dilihat dari belum adanya kepastian hukum secara eksplisit mengenai penyelesaian sengketa secara online di Indonesia. Penyelesaian sengketa bisnis secara konvensional pada umumnya diselesaikan melalui pengadilan atau litigasi. Proses litigasi lebih menyebabkan posisi para pihak yang berlawanan jauh dari konsep integrasi yang bersifat winwin solution namun lebih kepada win-lose solution. Proses penyelesaian melalui litigasi membutuhkan waktu yang cukup lama dan menyebabkan ketidakpastian bagi para pihak yang bersengketa. ${ }^{5}$ Penyelesaian sengketa secara konvensional cenderung yang lambat dan merugikan para pencari keadilan dalam segala aspek, terkhusus apabila menyangkut dalam dunia bisnis karena mengakibatkan ekonomi biaya tinggi, serta dapat menguras potensi serta sumber daya pihak yang yang bersengketa sedangkan didalam dunia bisnis diperlukan penyelesaian sengketa cepat, biaya murah, serta informal procedure.

Kehadiran e-commerce dimaksudkan untuk meniadakan kesulitankesulitan dalam transaksi bisnis yang konvensional sehingga penyelesaian sengketa melalui peradilan tentu saja tidak diharapkan untuk dilakukan karena hanya membuang waktu dan biaya. ${ }^{6}$ Didalam dunia bisnis saat ini, penyelesaian sengketa melalui pengadilan atau litigasi dominan tidak diminitai oleh banyak pihak. Adapun akhirnya penyelesaian dilakukan melalui lembaga peradilan atau litigasi, hal ini semata-mata hanya sebagai jalan yang terakhir (ultimatum remedium) setelah upaya lain tidak membuahkan hasil. Melihat kondisi saat ini, diperlukan suatu sistem yang tepat, efektif dan efisien. Untuk menjawab hal ini, maka dunia bisnis modern berpaling pada online dispute resulution sebagai penyelesaian sengketa modern karena kebutuhan akan penyelesaian sengketa dengan cepat dan biaya yang murah. ${ }^{7}$

${ }^{5}$ ibid.

${ }^{6}$ Purwanto, 'Efektifitas Penerapan Alternative Dispute Resolution (ADR) Pada Penyelesaian Sengketa Bisnis Asuransi Di Indonesia’ (2005) 1 Risalah Hukum.. h.14 sebagaimana dikutip Rochani Urip Salami dan Rahadi Wasi Bintoro (n 3).

7 Rochani Urip Salami dan Rahadi Wasi Bintoro (n 3). 
Online dispute resulution memberikan solusi yang sangat baik dalam menyelesaiakan sengketa perdagangan yang dipisahkan oleh letak geografis, bahkan antar negara. Meningkatnya masyarakat gelombang ketiga yang ditandai dengan interaksi dengan perangkat teknologi informasi menyebabkan perdagangan konvensional beralih kepada system yang lebih modern dengan memadukan hukum, ekonomi, manajemen dan teknologi ${ }^{8}$ Penggunaan teknologi informasi dalam sistem penyelesaian sengketa sangat membantu para pihak yang berada di lintas negara sehingga membuka alternatif baru bagi para pencari keadilan (justiciable) dalam menyelesaikan sengketanya.

Indonesia merupakan lahan bisnis yang dianggap sebagai wilayah produktif dan strategis dalam menanamkan bisnis dengan skala internasional. Indonesia merupakan salah satu negara yang memiliki pengaruh perekonomian yang besar di mata internasional dengan populasi penduduk yang kurang lebih dari 250 juta penduduk menempatkan Indonesia dalam posisi yang sangat strategis dalam intensitas transaksi bisnis domestik maupun internasional. Besarnya frekuensi kegiatan bisnis tersebut memicu meningkatnya jumlah sengketa yang terjadi sedangkan penyelesaian sengketa secara konvensional (non-litigasi) dianggap sudah tidak mampu menyeimbangi dari permasalahan tersebut. Hal lain yang menjadi permalasahan yakni hukum yang mengatur mengenai penyelesaian sengketa secara online di Indonesia masih diatur secara lex generale namun belum diatur secara lex specialist.

Hal-hal demikian yang pada akhirnya Negara dituntut pada pembaruan hukum pada penyelesaian sengketa secara online di Indonesia yang dianggap lebih "cepat, sederhana, dan biaya murah" sehingga para pelaku bisnis dapat menyelesaikan sengektanya berdasarkan asas tersebut. Penyeselaian sengekta secara online juga dianggap penyeimbang laju perkembangan era teknologi dan informasi, sehingga penerapan penyelesaian secara online dianggap penting dalam pembaruan hukum di Indonesia.

8 Adel Chandra (n 4).Loc.Cit.[80]. 


\section{Metode Penyelesaian Sengketa secara Online}

Pada umumnya sengketa bisnis dapat diselesaikan melalui 2 (dua) cara yakni dengan proses litigasi dan non-litigasi. Era digital saat ini menawarkan suatu solusi yang kreatif dan inovatif dengan melibatkan teknologi dan internet sebagai faktor pendukung dalam menyelesaikan suatu sengketa yang timbul dari suatu aktifitas perdagangan. Penyelesaian sengketa bisnis pada era digital dapat melalui internet yang kemudian dikenal dengan sebutan online dispute resolution. Pablo Cortes memberikan definisi online dispute resolution dalam jurnalnya,

"Online dispute resolution in the consumer context refers to the use of ITC tools and methods (usually alternative to the court syste) employed by businesses and consumers (B2C) to settle conflicts that arise out of economic transactions between the parties, particularly in e-commerce". 9 (Cortes 2010)

Konteks perdagangan melalui pendapat Pablo Cortes dinyatakan bahwa online dispute resolution mengacu pada penggunaan ICT (Information and Communication Technology dalam komunikasi penyelesaian sengketa yang digunakan oleh para pebisnis dan konsumen (business to consument) untuk menyelesaikan sengketa yang muncul akibat transaksi ekonomi antara para pihak.

Dalam sistem penyelesaian sengketa konvensional terdapat 3 (tiga) pihak yang terlibat, yaitu pihak-pihak yang bersengketa dan pihak ketiga yang netral namun dalam sistem penyelesaian sengketa secara online memperkenalkan pihak keempat yaitu teknologi yang digunakan negosiator, mediator, dan arbiter dalam proses penyelesaian sengketanya. ${ }^{10}$ Penyelesaian sengketa secara online dilakukan oleh para pihak yang berada dalam wilayah batas negara (borderless) maupun lintas geografis tanpa harus bertemu muka (face to face). Penyelesaian sengketa secara online memiliki berbagai bentuk metode yaitu online negotiation, online mediation, online arbitration. ${ }^{11}$

\footnotetext{
${ }^{9}$ Pablo Cortes, 'Online Dispute Resolution for Consumers: Online Dispute Resolution Methods for Settling Businesses to Consumer Conflicts' (Oapen, 2007) <http://www.mediate.com/pdf/ cortes.pdf $>$ accessed 20 June 2019.

${ }^{10}$ Rifkin Janet Katsh, Online Dispute Resolution: Resolving Conclict in Cyberspace (Jossey Bass 2001).[93-116] sebagaimana yang dikutip Moch Basarah, Prosedur Alternatif Penyelesaian Sengketa Arbitrase Tradisional Dan Modern (Online) (Genta Publishing 2011).[122].

${ }^{11}$ ibid.[122].
} 


\section{Negosiasi Online}

Negoisasi adalah penyelesaian sengketa yang paling dasar dan yang paling tua digunakan oleh manusia. Negoisasi merupakan cara yang paling penting karena para pihak dapat mengawasi prosedur penyelesaian sengketanya dan setiap penyelesaiannya didasarkan pada kesepakatan para pihak. Istilah negoisasi tercantum didalam Pasal 1 Butir (10) Undang - Undang Nomor 30 Tahun 1999 disebutkan bahwa penyelesaian sengketa alternatif adalah lembaga penyelesaian sengketa atau beda pendapat melalui prosedur yang disepakati oleh para pihak. Pengertian negoisasi dapat berbeda-beda tergantung dari sudut pandang siapa yang terlibat dalam suatu negoisasi. Negoisasi didefinisikan sebagai pembicaraan dengan orang lain dengan maksud untuk mencapai kompromi atau kesepakatan. Negoisasi bukan untuk mencari pemenang dan kalah, dalam setiap negoisasi terdapat kesempatan untuk menggunakan kemampuan sosial dan komunikasi efektif serta kreatif untuk membawa kedua belah pihak kearah hasil yang positif bagi kepentingan bersama. ${ }^{12}$

Negoisasi diperlukan dalam kehidupan manusia karena sifatnya yang begitu erat dengan filososfi kehidupan manusia dimana setiap manusia sifat dasar untuk mempertahankan kepentingannya, disatu sisi manusia lain juga memiliki kepentingan yang akan tetap dipertahankan sehingga terjadilah benturan kepentingan. Padahal kedua pihak tersebut memiliki suatu tujuan yang sama, yaitu memenuhi kepentingan dan kebutuhannya. Apabila terjadi benturan kepentingan terhadap suatu hal dengan demikian timbul suatu sengketa. Dalam penyelesaian sengketa dikenal berbagai macam cara, salah satunya negoisasi. Secara umum, tujuan dilakukannya negoisasi adalah mendapatkan dan memenuhi kepentingan yang telah direncanakan sebelumnya dimana hal untuk mendapatkan yang diinginkan. ${ }^{13}$ Dalam setiap proses negoisasi, selalu ada 2 (dua) belah pihak yang berbeda sudut pandangnya. Agar dapat menemukan, kedua belah pihak perlu bernegoisasi agar harapan win-win solution. Ketika pihak yang berkepentingan merasa puas dengan hasilnya, mereka akan membuat perjanjian itu berhasil, tidak sebaliknya. Alternatif penyelesaian sengketa

\footnotetext{
${ }^{12}$ Sri Hajati dkk, Politik Hukum Pertanahan (Airlangga University Press 2018). [430].

${ }^{13}$ ibid. [430].
} 
melalui negoisasi memiliki beberapa kelebihan, yakni diantaranya adalah: ${ }^{14}$

1. Negoisasi memberi peluang yang sangat luas bagi para pihak untuk menentukan pilihan-pilihannya;

2. Tidak tergantung pada norma hukum tertulis;

3. Dapat memberikan ruang bagi para pihak untuk bisa menang secara bersamasama (win-win solution);

4. Semua pihak memperoleh kesempatan untuk menjelaskan berbagai persoalan dalam proses negoisasi.

Sedangkan yang menjadi kelemahan dari alternatif penyelesaian sengketa melalui lembaga negoisasi ini, yakni diantaranya adalah :

1. Tidak dapat berjalan tanpa adanya kesepakatan atau tidak adanya kepercayaan antara para pihak yang bersengketa dalam menyelesaikan suatu sengketa tertentu;

2. Dalam negoisasi seringkali yang terjadi adalah tidak ada satu upayapun untuk mencoba saling mendengarkan kehendak dan keinginan masing-masing pihak;

3. Sulit berjalan apabila posisi para pihak tidak seimbang;

4. Dapat membuat kesepakatan yang kurang menguntungkan.

Dalam Business Law, Principles, Cases and Policy karya Mark E. Roszkowski, "Negoitation is a process by which two parties, with differing demands reach an agreement generally through compromise and concession". ${ }^{15}$ (Mark 2011).

Negoisasi merupakan suatu pranata alternatif penyelesaian sengketa yang bersifat informal procedure dan formal procedure. Kesepakatan tertulis hasil negoisasi adalah persetujuan diantara pihak maka selayaknya hasil negoisasi tidak dapat dibantah dengan alasan kekhilafan mengenai hukum atau dengan alasan bahwa salah satu pihak telah dirugikan. Walau demikian masih terbuka kemungkinan untuk tetap dapat dibatalkan, jika memang dapat dibuktikan menjadi suatu kekhilafan mengenai orangnya, mengenai pokok sengketa, telah dilakukan penipuan atau paksaan, dan kesepakatan telah diadakan atas dasar surat-surat yang kemudian dinyatakan palsu. ${ }^{16}$ Terdapat 2 (dua) jenis metode dalam mediasi online, yaitu :

1. Assisted negotiation adalah pemberian saran yang diberikan kepada para pihak yang bersengketa yang dirancang melalui peningkatan kemampuan teknologi

\footnotetext{
${ }^{14}$ ibid.[430].

15 Mark E. Roszkwoski, 'Business Law, Principles, Cases and Policy' (Amazon) <https:// www.amazon.com/Business-Law-Principles-Cases-Policy > accessed 26 June 2019.

${ }^{16}$ Ibid.
} 
untuk mencapai penyelesaian. E-mail merupakan versi pertama software mediation yang dimana telah dianggap sebagai bentuk software negosiasi yang primitif. Model tersebut telah dapat diganti dengan sarana yang jauh lebih canggih dan modern dengan model berbasis web yang mempunyai berbagai kemudahan. Apabila keberhasilan dicapai dengan menggunakan sistem e-mail maka keberhasilan lebih besar dapat dicapai dengan menggunakan model berbasis web yang lebih modern.

2. Automated negotiation adalah perbandingan antara tawaran dengan kesepakatan persetujuan yang dijalankan tanpa campur tangan manusia. Automated negotiation merupakan bentuk dari assisted negotiation yang dimana para pihak dibantu oleh teknologi sebagai fasilitator dalam menyelesaikan masalah tersebut. Metode ini disebut penawaran buta karena semua penawaran masih rahasia, dalam arti tidak diperlihatkan pada pihak lawan sampai mereka mendekati kesepakatan. ${ }^{17}$

Negosiasi merupakan mekanisme yang diprioritaskan karena para pihak bersengketa dapat berkomunikasi satu sama lain secara langsung.. Negoisasi merupakan cara yang dapat pertama kali ditempuh ketika para pihak bersengketa karena proses yang dimanfaatkan dapat memenuhi kebutuhan ketika ada pihak lain yang menguasai apa yang diinginkan. ${ }^{18}$ Negoisasi online merupakan bentuk penyelesaian sengketa oleh para pihak sendiri dengan bermusyawarah atau berunding untuk mencari pemecahan yang dianggap adil oleh para pihak dengan bantuan teknologi sebagai fasilitator. Hasil dari negoisasi tersebut dapat berupa keputusan secara kompromi (compromi solution). ${ }^{19}$

\section{Mediasi Online}

Mediasi adalah proses pemecahan konflik atau sengketa dimana pihak ketiga yakni mediator tidak memihak (impartial) atau bersifat netral dan dapat bekerjasama

\footnotetext{
17 ibid.

${ }_{18}$ Priyatna Abdurrasyid, Arbitrase Dan Alternatif Penyelesaian Sengketa (APS) (Fikahati Aneska 2011).

${ }^{19}$ Abdul Halim Barkatullah (n 1).[14].
} 
dengan pihak yang bersengketa untuk membantu memperoleh kesepakatan yang memuaskan kedua belah pihak. Dalam penerapannya, penyelesaian sengketa secara online dibantu oleh pihak keempat yakni teknologi untuk mencapai kesepakatan bersifat win-win solution. Alternatif penyelesaian sengketa melalui mediasi memiliki beberapa kelebihan: ${ }^{20}$

1. Keputusan yang hemat;

2. Penyelesaian secara cepat;

3. Hasil yang memuaskan bagi seluruh pihak;

4. Kesepakatan yang komrehensif;

5. Keputusan-keputusan yang bisa dilaksanakan;

6. Keputusan yang berlaku tanpa mengenal waktu.

Kelemahan pada proses mediasi adalah pada kekuatan ekseskusi setelah mencapai kesepakatan karena kesepakatan hanya dapat dicapai dengan cara sukarela oleh para pihak. Oleh karena itu, proses mediasi hanya akan efektif diterapkan kepada para pihak yang sukarela mengehendaki perselisihan yang diselesaikan dengan cara mediasi. Mediasi mempunyai konsep yang sama dengan ishlah. Secara harfiah, ishlah mengandung pengertian memutus pertengkaran atau perselisihan. Perdamaian dapat dicapai apabila terdapat dua pihak yang sebelumnya diantara mereka ada suatu persengketaan yang kemudian para pihak sepakat untuk saling melepaskan semua atau sebagian dari tuntutannya, hal ini dimaksudkan agar persengketaan diantara mereka dapat berakhir dengan win-win solution sehingga kesepakatan yang didapat diterima oleh kedua belah pihak yang sebelumnya bersengketa. ${ }^{21}$ Dalam Black's Law Dictionary memberikan definisi dari mediasi dan mediator,

"Mediation is private, informal dispute resolution process in which a neutral third person, the mediator helps disputing parties to reach an agreement. The Mediator has no power to impose a decission on the parties". ${ }^{22}$ (Black's, Dictionary Law 2009).

Selanjutnya definisi kesepakatan dari mediasi dapat dilihat dalam ketentuan yang diatur dalam WIPO Mediation Rules dinyatakan,

\footnotetext{
${ }^{20}$ Sri Hajati dkk (n 12). Op.Cit.[433].

${ }^{21}$ Widjaja Gunawan, Alternatif Penyelesaian Sengketa (2nd edn, PT Raja Grafindo Persada 2004).[89].

${ }^{22}$ Black's Law Dictionary.[1070-1071].
} 
"Mediation Agreement means an agreement by the parties to submit to mediation all or certain disputes which have arisen or which may arise between them; a Mediation Agreement may be in the form of a mediation clause in a contract or in the form of a separate contract. The mediation shall be conducted in the manner agreed by the parties. If, and to the extend that, yhe parties have not made such agreement, the mediator shall, in accordance with the rules, determine the manner in which the mediation shall be conducted. Each party shall coorporate in good faith with the mediator to advance the mediation as expedtiously as possible ${ }^{23}$ (WIPO Mediation Rules 1994)

Definisi dari mediasi yang diatas dinyatakan dengan jelas bahwa mediasi melibatkan keberadaan pihak ketiga baik perseorangan maupun dalam bentuk suatu lembaga independen yang bersifat netral dan tidak memihak yang berfungsi sebagai mediator. Sebagai pihak ketiga yang netral, independen, tidak memihak dapat ditunjuk oleh para pihak secara langsung maupun melalui lembaga mediasi. Dalam hal ini, mediator berkewajiban untuk melaksanakan tugas dan fungsinya bedasarkan pada kehendak dan kemauan para pihak yang bersengketa melalui proses perundingan dari para pihak. ${ }^{24}$ Terdapat 3 (tiga) jenis metode dalam mediasi online, yakni :25

1. Mediasi yang bersifat fasilitatifadalah mediator hanya berfungsi sebagai fasilitator dan tidak dapat memberikan opini atau merekomendasikan penyelesaian. Dalam hal ini, mediator memberikan jalan agar para pihak menemukan sendiri penyelesaian bagi sengketa yang dihadapinya.

2. Mediasi yang bersifat evaluatif adalah mediator memberikan pandangan dari segi hukum, fakta dan bukti. Strategi mediasi ini yaitu membuat suatu kesepakatan mealui mediator dengan memberikan solusi yang dapat diterima kedua belah pihak dan mencoba membujuk para pihak untuk menerimanya.

3. Mediasi yang bersifat situasional adalah mediator mencoba mencampuri permasalahan sejauh disetujui para pihak. Mediator hanya masuk jika para pihak gagal melakukan mediasi diantara mereka sendiri, mediator dapat mencampuri hanya sebatas mengajukan solusi apabila para pihak meminta kepadanya. Tujuan awal dari prosedur ini yaitu membantu memfasilitasi komunikasi antara para pihak dengan mediator dan antara para pihak sendiri.

Mediasi online juga dapat diterapkan hal yang demikian dengan komunikasi yang dijalankan dengan menggunakan teknologi yang tersedia seperti internet relay

\footnotetext{
${ }^{23}$ WIPO Mediation Rules.[1994].

${ }^{24}$ Peraturan Mahkamah Agung No. 2 Tahun 2003 tentang Prosedur Mediasi di Pengadilan.

${ }^{25}$ Priyatna Abdurrasyid (n 18).Op.Cit.[94].
} 
chats, e-mail, dan video conference sebagai elemen dasar dalam mediasi online yang merupakan sarana komunikasi antar pihak yang bersengktea beserta mediator.

\section{Arbitrase Online}

Arbitrase adalah forum penyelesaian sengketa diluar pengadilan yang saat ini banyak dipilih oleh pelaku usaha.karena ketidakpercayaan kepada pengadilan, proses arbitrase relatif cepat, pelaksanaannya yang menjunjung tinggi asas konfidensialitas (kerahasiaan), para pihak bebas memilih arbiter dengan pertimbangan keahlian (expert), dan yang lebih penting lagi adalah para pihak bebas memilih hukum yang akan dipakai dalam proses arbitrase dan putusan yang dihasilkan bersifat final and binding. ${ }^{26}$ Pasal 1 Angka 1 Undang - Undang Nomor 30 Tahun 1999 menerangkan arbitrase merupakan cara penyelesaian sengketa perdata diluar peradilan umum yang didasarkan pada perjanjian arbitrase yang dibuat secara tertulis oleh para pihak yang bersengketa. Kelebihan dari alternatif penyelesaian sengketa melalui lembaga arbitrase ini adalah diantaranya, yakni: ${ }^{27}$

1. Adanya jaminan kerahasiaan sengeketa para pihak;

2. Dapat dihindarkan keterlambatan yang diakibatkan karena hal prosedural dan administratif;

3. Para pihak dapat memilih hukum apa yang akan diterapkan untuk penyelesaian masalahnya serta proses dan tempat penyelenggaraan arbitrase.

Kelemahan dari proses arbitrase tersebut karena lembaga arbitrase tidak memiliki kekuatan ekskutorial dan kepastian hukum terhadap kesepakatan yang telah dihasilkan. Arbitrase online juga menggunakan jasa arbiter sebagai pihak ketiga yang bersifat netral sebagai pembuat keputusan dan dibantu oleh pihak keempat yaitu teknologi dan internet. Moch. Basarah memberikan pengertian arbitrase online,

"Arbitration, where parties make their case to a neutral party who does have decision making authority. Arbitration works like a courtroom, the arbitrator is a judge, and after hearing both sides renders a decision. This decision can

26 Bambang Sutiyoso, Penyelesaian Sengketa Bisnis (Rajawali 2004).[222] sebagaimana yang dikutip Abdul Halim Barkatullah (n 1).Op.cit.[16].

${ }^{27}$ Sri Hajati dkk (n 12).Op.Cit.[433]. 
be either binding or non binding, depending on what the parties agree to before take arbritation take place". ${ }^{28}$

Putusan arbitrase dapat bersifat binding and non binding tergantung kepada kesepakatan para pihak sebelum putusan itu dilaksanakan, dalam hal ini sifat etika para pihak sangat bermanfaat jika didukung dan dilandasi good faith, corporation, dan non-concrontation. Terdapat 2 (dua) jenis metode berdasarkan dalam arbitrase online, yakni :

1. Arbitrase bersifat mengikat adalah arbitrase yang putusannya bersifat final, sehingga mengikat selayaknya putusan Pengadilan yang telah inkrah.

2. Arbitrase bersifat tidak mangikat adalah arbitrase yang putusannya bersifat opsi, boleh diikuti dan boleh tidak diikuti selayaknya seperti fact finding.

Pada umumnya penyelesaian sengketa dengan metode arbitarase online juga melibatkan pihak ketiga yaitu arbiter yang bersifat netral sebagai pembuat keputusan yang dibantu oleh pihak keempat yaitu teknologi dan internet sebagai fasilitator dalam proses penyelesaian sengketa para pihak.

\section{Konsep Penyelesaian Sengketa Online dalam Perundang-undangan di Indonesia}

Penyelesaian sengekta secara online telah dikonsepsikan dalam perundangundangan di Indonesia. Hal ini dapat dilihat pada perundangan-undangan yang berlaku pada hukum positif di Indonesia yakni diantaranya pada Undang - Undang Nomor 30 Tahun 1999 tentang Arbitrase dan Alternatif Penyelesaian Sengketa, Undang - Undang Nomor 11 Tahun 2008 tentang Informasi dan Transasksi Elektronik, dan Undang - Undang Nomor 7 Tahun 2014 tentang Perdagangan. Ketiga perundangan-undangan tersebut secara "lex generale" sudah dapat memayungi prospek terhadap penyelesaian sengketa secara online di Indonesia.

Penerapan penyelesaian sengketa secara online di Indonesia membutuhkan beberapa faktor-faktor pendukung agar dapat diterapkan, salah satunya adalah faktor payung hukum sehingga demi kepastian hukum bagi masyarakat dan para pelaku

${ }^{28}$ Moch Basarah (n 10).[122]. 
bisnis pada khususnya dibutuhkan "lex specialis" terhadap prospek penerapan penyelesaian sengketa secara online. Hukum positif Indonesia telah mengatur dan membuka selebar-lebarnya penyelesaian sengketa non-litigasi melalui Undang - Undang Nomor 30 Tahun 1999 tentang Arbitrase dan Alternatif Penyelesaian Sengketa yang merupakan dasar bagi penerapan penyelesaian sengketa secara online di Indonesia dengan metode online negotitation, online mediation, dan online arbitration. Disisi lain, penerapan penyelesaian sengketa secara online juga didorong oleh Undang - Undang Nomor 11 Tahun 2008 tentang Informasi dan Transasksi Elektronik beserta Undang - Undang Nomor 7 Tahun 2014 tentang Perdagangan sebagai dasar pembuktian elektronik dan lembaga non-litigasi melalui dunia maya (cyber word).

\section{Konsep Penyelesaian Sengketa secara Online dalam Undang - Undang Nomor 30 Tahun 1999 tentang Arbitrase dan Alternatif Penyelesaian Sengketa}

Konsepsi pemikiran bahwa hukum sebagai sarana pembaruan masyarakat adalah keharusan mutlak karena merupakan jelmaan dari keinginan masyarakat dalam usaha pembangunan dan pembaruan dibidang ekonomi demi terjaganya ketertiban di Indonesia. Hal ini kemudian mendorong terbentuknya pengaturan penyelesaian sengketa bisnis yang lebih cepat. Pasal 1 Angka (10) Undang - Undang Nomor 30 Tahun 1999 menyebutkan bahwa metode penyelesaian sengketa diluar pengadilan antara lain berupa konsultasi, negosiasi, mediasi, konsiliasi, penilaian ahli, arbitrase.

Metode penyelesaian sengketa diluar pengadilan memberikan peluang kepada pihak-pihak yang bersengketa memilih cara yang terbaik dalam menyelesaikan sengketanya. Penyelesaian sengketa secara online pada dasarnya termasuk ke dalam ranah hukum perjanjian sehingga berlaku asas kebebasan berkontrak, artinya para pihak bebas melakukan pilihan hukum dan pilihan forum penyelesaian sengketa yang akan dipakai apabila terjadi sengketa keperdataan. Pasal 1 Angka (10) Undang - Undang Nomor 30 Tahun 1999 tentang Arbitrase dan Alternatif Penyelesaian Sengketa telah mendorong metode-metode penyelesaian sengketa diluar pengadilan melalui teknologi dan komunikasi sesuai dengan perkembangan 
zaman yang mengalami modernisasi sehingga keadaan geografis bukanlah menjadi penghalang lagi saat ini. ${ }^{29}$

\section{Konsep Penyelesaian Sengketa secara Online dalam Undang - Undang Nomor 11 Tahun 2008 tentang Informasi dan Transaksi Elektronik}

Urgensi pemikiran tentang pentingnya pengaturan praktek kontrak elektronik di Indonesia melahirkan Undang - Undang Nomor 11 Tahun 2008 tentang Informasi dan Transaksi Elektronik. Penyelesaian sengketa transaksi elektronik diatur dalam Pasal 18 Ayat (4) Undang - Undang Nomor 11 Tahun 2008 tentang Informasi dan Transaksi Elektronik menerangkan :

1. Transaksi elektronik yang dituangkan ke dalam kontrak elektronik mengikat para pihak;

2. Para pihak memiliki kewenangan untuk memilih hukum yang berlaku bagi transaksi internasional yang dibuatnya;

3. Jika para pihak tidak melakukan pilihan hukum dalam transaksi elektronik internasional, hukum yang berlaku didasarkan pada asas hukum perdata internasional;

4. Para pihak memiliki kewenangan untuk menetapkan forum pengadilan, arbitrase, atau lembaga penyelesaian sengketa alternatif lainnya yang berwenang menangani sengketa yang mungkin timbul dari transaksi elektronik internasional yang dibuatnya;

5. Jika para pihak tidak melakukan pilihan forum sebagaimana dimaksud dalam ayat (4) penetapan kewenangan pengadilan, arbitrase, atau lembaga penyelesaian sengketa alternatif lainnya yang berwenang menangani sengketa yang mungkin timbul dari transaksi tersebut, didasarkan pada asas hukum Internasional.

Berdasarkan Pasal 38 Ayat (1) diterangkan bahwa penegakan hukum berasal dari masyarakat dan bertujuan untuk mencapai kedamaian dan ketertiban umum. Masyarakat turut berperan aktif dalam setiap hal seperti pemanfaatan teknologi, seperti perdagangan elektronik (e-commerce), pembayaran elektronik (e-payment), penandatanganan kontrak kerja secara elektronik (e-contract), dan bentuk-bentuk lainnya dalam media teknologi informasi. Hal demikian mempertegas bahwa dalam perundang-undangan tersebut Indonesia dapat dikatakan mendukung pembentukan penyelesaian sengketa secara online. Hal lain yang menjadi faktor pendorong yakni

${ }^{29}$ ibid.[122]. 
disebutkan didalam ketentuan Pasal 41 Undang - Undang Nomor 11 Tahun 2008 tentang Informasi dan Transaksi Elektronik :

1. Masyarakat dapat berperan meningkatkan pemanfaatan teknologi informasi melalui penyelenggaraan sistem elektronik dan transaksi elektronik.

2. Peran masyarakat sebagaimana pada ayat (1) dapat diselenggarakan melalui lembaga yang dibentuk oleh masyarakat.

3. Lembaga dapat memiliki fungsi konsultasi dan mediasi.

Berdasarkan penjelasan Pasal 41 Undang - Undang Nomor 11 Tahun 2008 tersebut, yang dimaksud dengan "lembaga yang dibentuk oleh masyarakat" adalah lembaga yang bergerak dibidang teknologi informasi dan transaksi elektronik. Hal tersebut membuka kemungkinan untuk masyarakat membuat lembaga yang berfungsi untuk menyelesaikan sengketa secara online di Indonesia.

\section{Konsep Penyelesaian Sengketa secara Online dalam Undang - Undang Nomor 7 Tahun 2014 tentang Perdagangan}

Konsepsi pada pengaturan e-commerce merupakan amanah dari Undang Undang Nomor 7 Tahun 2014 tentang Perdagangan. Pertumbuhan ekonomi yang pesat dan kompleks melahirkan berbagai macam bentuk kerja sama bisnis baik dalam barang maupun jasa. Dalam dunia yang semakin modern serta kegiatan bisnis yang semakin meningkat, maka tidak mungkin dihindari terjadinya sengketa yang muncul dikarenakan berbagai faktor dan masalah yang melatar belakanginya, terutama karena adanya conflict of interest. Hal tersebut menjadi pekerjaan rumah bagi Negara karena tuntutan oleh masyarakatnya agar menciptakan payung hukum yang dapat melindungi semua aktifitas perdagangan di Indonesia. Merujuk kepada Pasal 65 Ayat (5) Undang - Undang Nomor 7 Tahun 2014 tentang Perdagangan diterangkan,

"Dalam hal terjadi sengketa terkait transaksi dagang melalui sistem elektronik, orang atau badan usaha yang mengalami sengketa dapat menyelesaikan sengketa tersebut melalui pengadilan atau melalui mekanisme penyelesaian sengketa lainnya”. ${ }^{30}$ (Undang-Undang No.7 2014).

\footnotetext{
${ }^{30}$ Pasal 65 Ayat (5) UU Nomor 7 Tahun 2014 tentang Perdagangan
} 
Berdasarkan ketentuan dalam Pasal 65 Ayat (5) ialah para pihak yang bersengketa diberikan kebebasan untuk memilih lembaga penyelesaian sengketanya baik melalui pengadilan ataupun melalui mekanisme penyelesaian sengketa lainnya. Hal tersebut merupakan faktor pendorong untuk diterapkannya lembaga penyelesaian sengketa secara online di Indonesia.

\section{Kesimpulan}

Penyelesaian sengketa secara online merupakan salah satu wujud pembaruan dan pembangunan dibidang perdagangan secara modern yang berasal dari wujud penyelesaian sengketakonvensional. Penyelesaian sengketa secara online merupakan penyelesaian sengketa yang dikembangkan dengan teknologi dan internet melalui dunia maya (cyber space) sehingga lebih memudahkan dan menguntungkan bagi pelaku bisnis dalam upaya penyelesaian sengketa yang timbul dari segala aktifitas bisnis baik dari business to business, consument to business, maupun consument to consument. Dalam dewasa ini, penyelesaian sengketa secara online lebih dominan diminati pelaku bisnis karena faktor penyelesaiannya yang lebih sederhana, cepat, dan hemat biaya mengingat dalam dunia bisnis waktu dan biaya merupakan faktor vital dalam aktifitas bisnis.

Prospek penerapan penyelesaian sengketa secara online di Indonesia telah dikonsepkan kedalam wujud Undang - Undang Nomor 30 Tahun 1999 tentang Arbitrase dan Alternatif Penyelesaian Sengketa, Undang - Undang Nomor 11 Tahun 2008 tentang Informasi dan Teknologi, dan Undang - Undang Nomor 7 Tahun 2014 tentang Perdagangan. Akhir kata, ketiga perundang - undangan tersebut sebenarnya telah memayungi secara umum (lex generale) mengenai prospek penerapan penyelesaian sengketa secara online di Indonesia namun masyarakat dan pelaku bisnis masih menuntut negara ini melakukan pambaruan hukum yang mengatur secara eksplisit (lex specialist) sehingga penyelesaian sengketa secara online kedepannya tidak mengalami kekosongan hukum serta memudahkan para pelaku bisnis dalam menyelesaikan sengketanya. 


\section{Daftar Bacaan}

\section{Buku}

Abdul Halim Barkatullah, Sengketa Transaksi E-Commerce Internasional (Nusa Media 2010).

Bambang Sutiyoso, Penyelesaian Sengketa Bisnis (Rajawali 2004).

Benjamin Wreight, The Law of Electronic Commerce (3rd edn, Aspen Law and Businesses 2001).

Moch Basarah, Prosedur Alternatif Penyelesaian Sengketa Arbitrase Tradisional Dan Modern (Online) (Genta Publishing 2011).

Priyatna Abdurrasyid, Arbitrase Dan Alternatif Penyelesaian Sengketa (APS) (Fikahati Aneska 2011).

Rifkin Janet Katsh, Online Dispute Resolution: Resolving Conclict in Cyberspace (Jossey Bass 2001).

Sri Hajati dkk, Politik Hukum Pertanahan (Airlangga University Press 2018).

Widjaja Gunawan, Alternatif Penyelesaian Sengketa (2nd edn, PT Raja Grafindo Persada 2004).

\section{Jurnal}

Purwanto, 'Efektifitas Penerapan Alternative Dispute Resolution (ADR) Pada Penyelesaian Sengketa Bisnis Asuransi Di Indonesia' (2005) 1 Risalah Hukum.

Rochani Urip Salami dan Rahadi Wasi Bintoro, 'Alternatif Penyelesaian Sengketa Dalam Sengketa Transaksi Elektronik (E-Commerce)’ (2013) 13 Dinamika Hukum.

Syamsiah Amali, 'Pemanfaatan Internet Pada Pelajar Di Kota Gorontalo' Jurnal Penelitian dan Komunikasi Opini Publik <https://kolomberbagi.files. wordpress.com/2011/10/pemanfaatan-internet-pada-pelajar-di-kotagorontalo.pdf>.

Topio Puurunen, 'The Judicial Juridiction of States Over International Busines to Consumer Electronic Commerce from The Perspective of Legal Certainty' [2002] Journal of International Law and Policy. 


\section{Laman}

Adel Chandra, 'Penyelesaian Sengketa Transaksi Melalui Online Dispute Resolution (ODR) Kaitan Dengan UU Informasi Dan Transaksi Elektronik No. 11 Tahun 2008' (Esa Unggul, 2014) <https://digilib.esaunggul.ac.id/penyelesaiansengketa-transaksi-elektronik-melalui-online-dispute-resolution-odr-kaitandengan-uu-informasi-dan-transaksi-elektronik-no11-tahun-2008-3653.html> accessed 15 January 2019.

Mark E. Roszkwoski, 'Business Law, Principles, Cases and Policy' (Amazon) $<$ https://www.amazon.com/Business-Law-Principles-Cases-Policy accessed 26 June 2019.

Pablo Cortes, 'Online Dispute Resolution for Consumers: Online Dispute Resolution Methods for Settling Businesses to Consumer Conflicts' (Oapen, $2007)<$ http://www.mediate.com/pdf/cortes.pdf $>$ accessed 20 June 2019.

HOW TO CITE: Muhammad Azwar, 'Prospek Penerapan Online Dispute Resolution dalam Upaya Penyelesaian Sengketa Bisnis di Indonesia' (2019) Vol. 2 No. 2 Media Iuris. 